\title{
Pulmonary endarterectomy for chronic pulmonary thromboembolism, Timisoara department experience 2004-2012
}

\author{
M Gaspar ${ }^{1 *}$, W Klepetko ${ }^{2}$, M Bogdan ${ }^{3}$ P Deutsch ${ }^{1}$ \\ From 23rd World Congress of the World Society of Cardio-Thoracic Surgeons \\ Split, Croatia. 12-15 September 2013
}

\section{Background}

The pulmonary thromboembolism, which may be subsequent or not to the deep venous thrombosis causes a serious disability, due to the severe pulmonary hypertension and right ventricular failure, with a life treating potential and very severe disability.

\section{Methods}

In 2004-2012, we performed 26 PEA, 9 female and 17 males, age between 23 and 87 years old. The clinical suspicion of the diagnosis is confirmed by pulmonary artery angiography CT-with contrast. Surgical treatment, although marked with a high risk, represents the only chance in the advanced stages of the disease. The operation is performed in extracorporeal circulation, deep hypothermia $20^{*} \mathrm{C}$, with several periods of total circulatory arrest, in order to facilitate the extraction of the thrombi from the pulmonary artery trunk and all the arterial pulmonary branches. As much as possible, all the thrombi should be extracted.

\section{Results}

Two patients died after surgery, both with additional comorbidities and surgical procedures (anomalous venous drainage, aortic stenosis respectively). The patient selection and surgical technique are essential for early and late postoperative evolution. They are symptomfree, with very good exercise ability NYHA I, social reintegration, 8 years postoperative. Anticoagulation should remain as long.

\section{Conclusions}

PEA is considered single curative treatment. Postoperative evolution in spite of longer stay on ICU is spectacular for the majority of the patients. They are only some centers doing this operation in Europe and the diagnosis is underestimated.

\section{Authors' details}

${ }^{1}$ Institute of Cardiovascular Disease, Timisoara, Romania. ${ }^{2}$ Department of Thoracic Surgery, AKH, Vienna, Austria. ${ }^{3}$ National Institute of Pneumology, Bucharest, Romania.

Published: 11 September 2013

doi:10.1186/1749-8090-8-S1-P149

Cite this article as: Gaspar et al:: Pulmonary endarterectomy for chronic pulmonary thromboembolism, Timisoara department experience 20042012. Journal of Cardiothoracic Surgery 2013 8(Suppl 1):P149.

* Correspondence: mariangaspar@yahoo.com

1 Institute of Cardiovascular Disease, Timisoara, Romania

Full list of author information is available at the end of the article

Submit your next manuscript to BioMed Central and take full advantage of:

- Convenient online submission

- Thorough peer review

- No space constraints or color figure charges

- Immediate publication on acceptance

- Inclusion in PubMed, CAS, Scopus and Google Scholar

- Research which is freely available for redistribution

Submit your manuscript at www.biomedcentral.com/submit
Biomed Central 